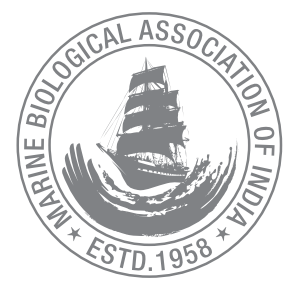

\title{
Marine macroalgal resources from nine beaches along the Kerala coast, India
}

\author{
M. S. Baby Ushakiran, Sr. M. V. Merlee Treasa, T. V. Sathianandan ${ }^{1}$ and P. Kaladharan ${ }^{1 *}$ \\ Department of Botany, St. Teresa's College, Ernakulam, Kerala, India. \\ ${ }^{1}$ ICAR-Central Marine Fisheries Research Institute, Kochi - 682 018, Kerala, India. \\ *Correspondence e-mail: kaladharanep@gmail.com
}

Received: 04 Jul 2016, Accepted: 20 June 2017, Published: 10 July 2017

Original Article

\begin{abstract}
Estimates of number, density and wet biomass of seaweed resources and their availability for exploitation for phycocolloid extraction along the Kerala coast in relation to water quality were studied using the data collected at quarterly intervals from nine stations during 1998 and 1999. A total of 37 species of seaweeds were collected and out of these, 13 were grouped under Class Chlorophyceae (green seaweeds), 7 under Phaeophyceae (brown seaweeds) and 17 under Rhodophyceae (red seaweeds). Agar yielding seaweeds were represented by seven species and the major resources were Gracilaria corticata, G. foliifera, Gelidiopsis variabilis and Gelidium pusillum during 1998 and 1999 besides the species of Pterocladia during 1999. Alginophytes were represented by Sargassum wightii, S. duplicatum, S. tenerimum, Stoechospermum marginatum, Dictyota dichotoma and Padina spp. The carrageenan yielding red seaweeds were more in number (nine species) belonging to seven Genera. Out of them, Hypnea musciformis, H. valentiae, Grateloupia filicina, G. lithophila and a new resource Gracilariopsis lemaneiformis, from Dhalavapuram and Kannur stations were available in considerable quantities. The richest diversity of seaweeds was observed at Mullur (Vizhinjam) and Thikkodi (Calicut) followed by Thirumallavaram (Quilon).
\end{abstract}

Keywords: Seaweeds, resource assessment, Kerala coast, hydrography, agarophytes

\section{Introduction}

All macroscopic algae occurring in the marine, coastal and brackish water habitats are termed as seaweeds. They are autotrophic non-flowering plants and grow either as free floating in the sea surface or attached on rocks, shells or on dead corals in intertidal and subtidal regions. In India luxuriant growth of several species of seaweeds occur along the southeast coast of Tamilnadu, Gujarat, Lakshadweep (Laccadives) and Andaman-Nicobar Islands (Umamaheswra Rao, 1969; Chennubhotla, 1996; Kaliaperumal, 1993). Indian coastline is endowed with 844 species of marine algae comprising 216 species of Chlorophyta, 191 species of Phaeophyta, 434 species of Rhodophyta and 3 species of Xanthophyta (Oza and Zaidi, 2001). From the seaweed resource surveys carried out in the intertidal and shallow water areas of east and west coasts and also the archipelago of Laccadives and Andamans so far by CMFRI Cochin, CSMCRI Bhavnagar and NIO Goa, it could be estimated that total standing crop of all the seaweeds in Indian waters is more than $2,60,876$ tonnes (wet weight) consisting of $6 \%$ of agar yielding red seaweeds, $16 \%$ of algin yielding brown seaweeds, $8 \%$ of carragenophytes and the remaining edible and other seaweeds (Devaraj et al., 1999). Recent developments on 
seaweed resources, their culture and utilization in India were reviewed by Baby Ushakiran et al. (2014).

Marine algal resources of southern Kerala coast including Ashtamudi Lake, Quilon and Trivandrum coasts were assessed qualitatively by Balakrishnan Nair et al. (1982, 1986, 1986a, 1990, 1993). Chennubhotla et al. (1988) conducted an extensive resource assessment survey along the Kerala coast and brought out the details of availability of economically important resources for the first time. Occurrence of Porphyra kanyakumariensis was reported from the southern Kerala coast by Chennubhotla et al. (1990). Gracilariopsis lemaneiformis, a long thalloid red alga has been reported from the Kumbala backwaters near mangrove patches along Kerala coast (Kaladharan, 2005). In this communication an attempt is made to assess the seaweed resources, density and their availability for exploitation for phycocolloid extraction along the Kerala coast in relation to water quality during 1998 and 1999.

\section{Material and methods}

Nine study sites as shown in Fig. 1 were selected along the Kerala coast after visiting the entire coast. Main criteria for selecting the study sites were approach through road and the presence of hard substratum for seaweed growth. The geographical locations of the study sites were marked with the help of hand held geographical positioning system (GPS mp 76 CSX, Garmin model). Seaweeds were collected from the above sites at quarterly intervals during 1998 \&1999 at low tide as recorded in the Indian Tide Table when the beach was exposed. The seaweeds collected from each sites were cleaned with seawater and brought to the laboratory separately for further observations. Density of macroscopic seaweeds from each study sites was estimated using a quadrate $\left(1 \mathrm{~m}^{2}\right)$. Five quadrats were laid randomly at each site to estimate the standing crop. Seaweeds present in each quadrat harvested were pooled together, washed thoroughly with seawater, brought to shore, and the wet biomass was estimated using a top pan balance, spread in a sheet, sorted by species and weighed separately. Afterwards, each species was put in separate polyethylene covers and brought to laboratory for processing. Based on the wet weight and density, the dominant species in a particular period from each study site was identified. Species were identified using the identification key prepared by Umamaheswara Rao (1987).

Standing stock of seaweed was estimated using the following formula.

$\mathrm{W}=\frac{w}{a}$

where $w$ is the standing stock of a particular species of a particular site, $\mathrm{w}$ is the wet biomass of seaweed harvested from 5 quadrates a is the total area studied i.e. $5 \mathrm{~m}^{2}$.

The hydrographic parameters such as water temperature (SST), pH, salinity, dissolved oxygen and the dissolved nutrients like phosphate and nitrate from the study sites were estimated quarterly using standard procedures (APHA, 1998; Parsons et al., 1984). Dissolved Phosphate was determined according to Murphy and Riley (1962). Nitrate dissolved in seawater was estimated according to the method of Morris and Riley (1963). The data collected were statistically analysed using SPSS software (version 13.0). For the comparison of different locations with respect to the harvestable biomass of different species of seaweeds, one way analysis of variance (ANOVA) were carried out using SPSS software (version 13.0). Seasonal difference in the harvestable biomass of different species of seaweeds was also tested using ANOVA.

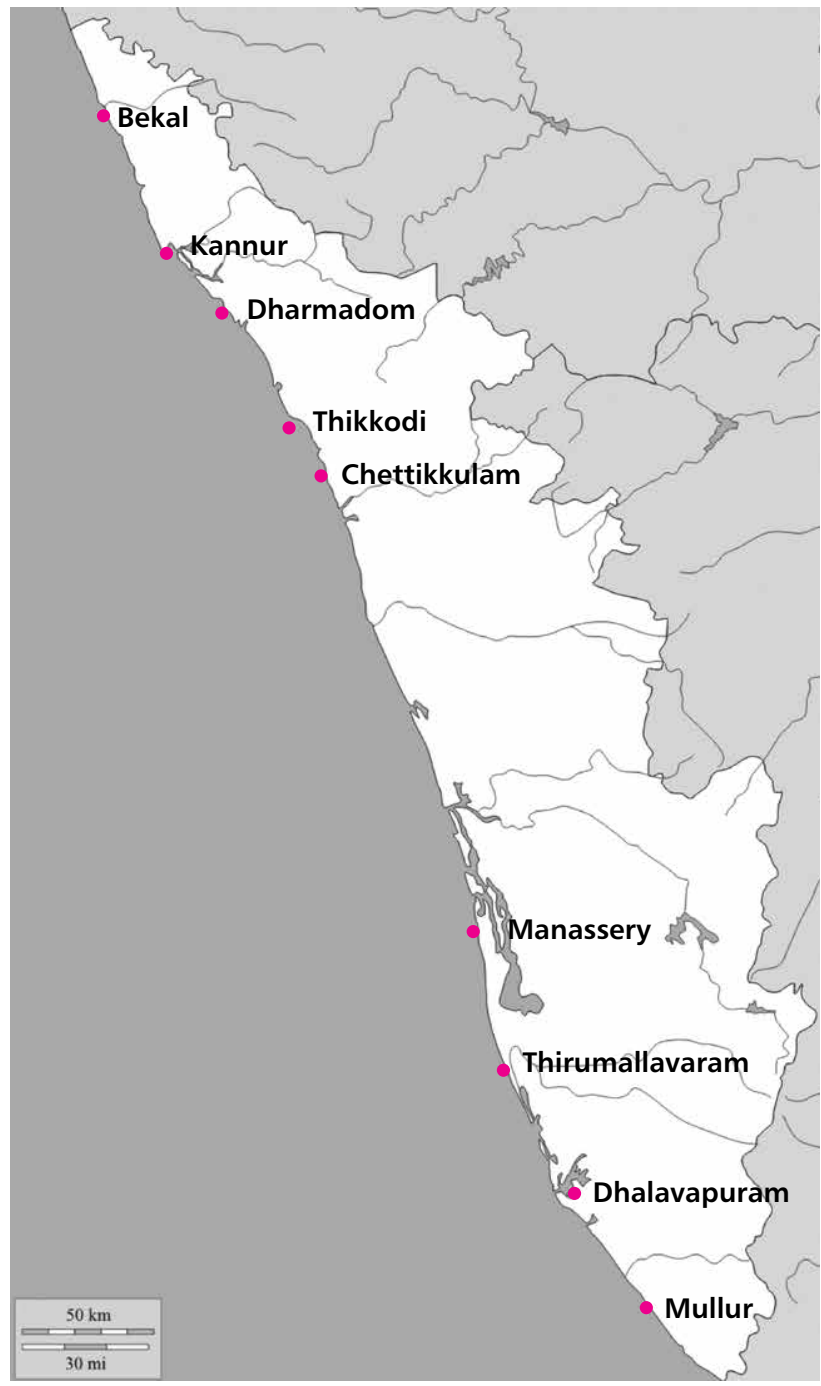

Fig.1 Sampling locations along Kerala coast 


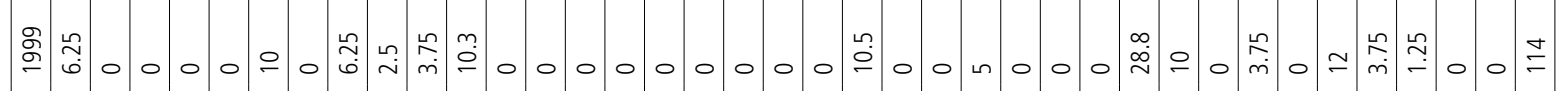

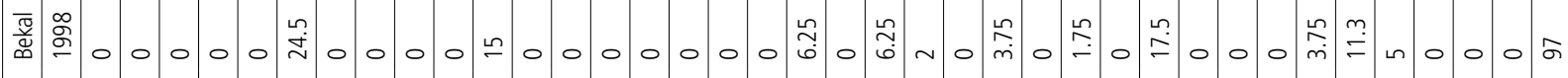

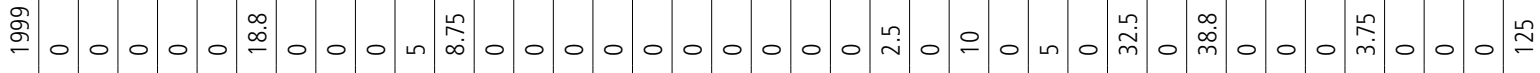
言壳点

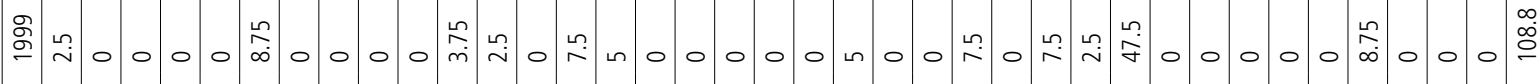

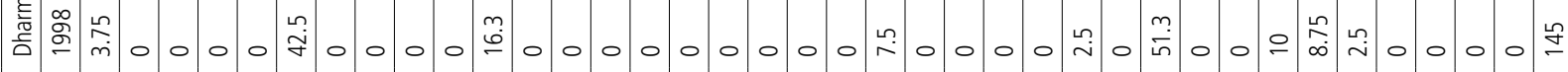

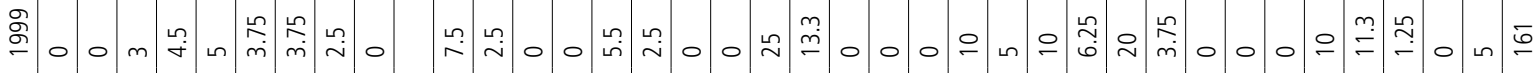
产

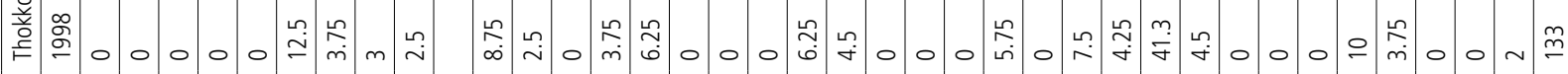

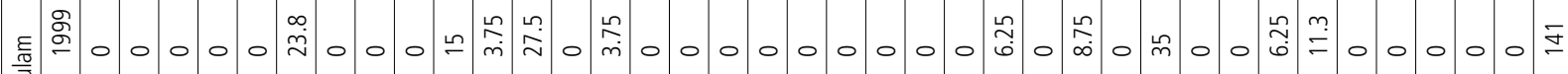

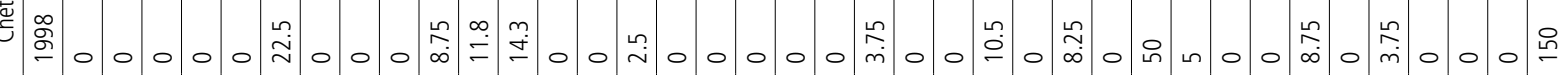
g. 离

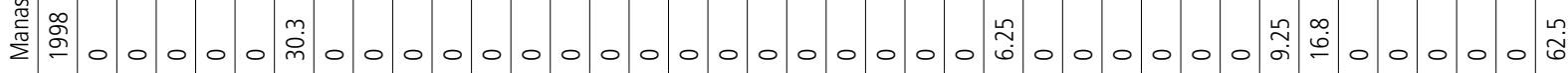

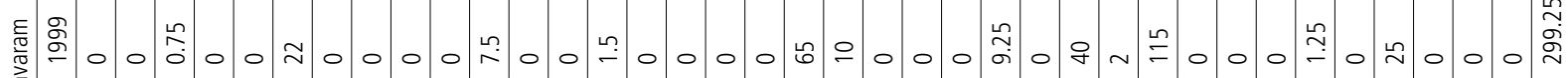

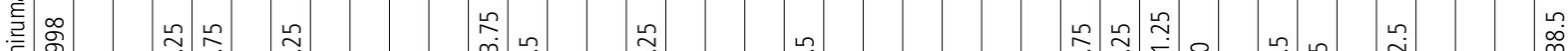

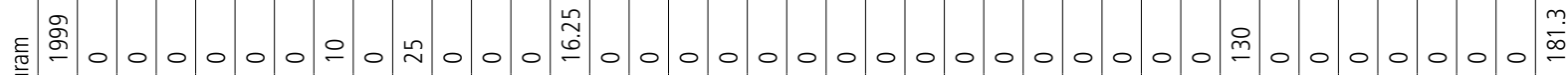

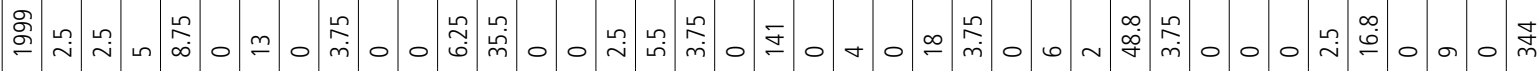

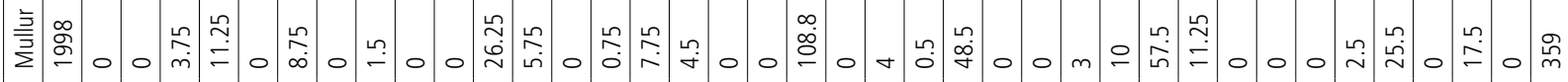




\section{Results}

Annual mean of wet biomass of seaweeds harvested from each collection sites (Fig. 1) along the Kerala coast during the four quarters of 1998 and 1999 are presented in Table 1 and the species of seaweeds collected from these sites are listed in Table 2.

\section{Mullur}

Mullur is a rocky coast and hence serves as an excellent substratum for seaweed growth. During the year 1998, Mullur coast registered $359 \mathrm{~g} / \mathrm{m}^{2}$ average wet biomass of seaweeds that can be harvested, ranging from $451 \mathrm{~g} / \mathrm{m}^{2}$ in March to 270 $\mathrm{g} / \mathrm{m}^{2}$ in December. Red seaweeds such as Hypnea valentiae $\left(25.5 \mathrm{~g} / \mathrm{m}^{2}\right)$, Asparagopsis taxiformis $\left(48.5 \mathrm{~g} / \mathrm{m}^{2}\right)$, Gracilaria corticata and $G$. foliifera $\left(73.75 \mathrm{~g} / \mathrm{m}^{2}\right)$ and brown seaweeds such as Sargassum wightii $\left(109 \mathrm{~g} / \mathrm{m}^{2}\right)$ were present throughout the year in appreciable quantities. However, the year 1999 registered an average wet biomass of $344 \mathrm{~g} / \mathrm{m}^{2}$ seaweeds ranging from $307 \mathrm{~g} / \mathrm{m}^{2}$ in March to $495 \mathrm{~g} / \mathrm{m}^{2}$ during June with only 6 species of seaweeds. Although during December the number of species increased to 17, the harvestable biomass was only $315 \mathrm{~g} / \mathrm{m}^{2}$ (Table 1). During June 1999 luxurient growth of green seaweed U/va fasciata $\left(100 \mathrm{~g} / \mathrm{m}^{2}\right)$ could be harvested. Mullur was identified as an excellent site in Kerala for collecting Sargassum wightii $\left(140.75 \mathrm{~g} / \mathrm{m}^{2}\right)$, the raw material for alginic acid production throughout the year.

\section{Dhalavapuram}

Dhalavapuram is a brackish water area in the Ashtamudi Lake system harbouring rich growth of red alga Gracilariopsis lemaneiformis. A total of five species of seaweeds could be collected during the study period (Table 1). The average seaweed biomass that could be harvested from Dhalavapuram was estimated to $173 \mathrm{~g} / \mathrm{m}^{2}$ during 1998 and $181 \mathrm{~g} / \mathrm{m}^{2}$ during 1999 . During March 1998, $180 \mathrm{~g} / \mathrm{m}^{2}$ of Gracilariopsis lemaneiformis was found growing along with the carrageenan yielding Hypnea musciformis and green seaweed Enteromorpha compressa. The last quarter also registered rich biomass of seaweeds $\left(200 \mathrm{~g} / \mathrm{m}^{2}\right)$ comprising fairly dense vegetation of Gracilariopsis lemaneiformis, Enteromorpha compressa and Chaetomorpha linum. Subdominant species were Enteromorpha compressa $\left(60 \mathrm{~g} / \mathrm{m}^{2}\right.$ in June and 50 $\mathrm{g} / \mathrm{m}^{2}$ in December) and U/va reticulata ( $40 \mathrm{~g} / \mathrm{m}^{2}$ in June). Another green seaweed, Chaetomorpha linum, was encountered during December in appreciable quantity $\left(40 \mathrm{~g} / \mathrm{m}^{2}\right)$.

\section{Thirumallavaram}

Thirumallavaram coast is characterized by laterite rocky substratum extending to shallow sea and known to harbour rich diversity (17 species) of seaweeds especially dense vegetation of carrageenan yielding Hypnea valentiae $\left(160 \mathrm{~g} / \mathrm{m}^{2}\right)$ and U/va fasciata $\left(140 \mathrm{~g} / \mathrm{m}^{2}\right.$ ) during December 1998 (mean wet biomass
Table 2. List of seaweeds collected from Kerala coast during 1998 and 1999

\begin{tabular}{|c|c|}
\hline SI.No & Species \\
\hline \multicolumn{2}{|c|}{ Chlorophyceae } \\
\hline 1 & Bryopsis plumosa, C. Agardh. \\
\hline 2 & Caulerpa cupressoides, C. Agardh. \\
\hline 3 & Caulerpa peltata, Lamour. \\
\hline 4 & Caulerpa racemosa, Forsskal \\
\hline 5 & Caulerpa sertularioides, F. Brevioes \\
\hline 6 & Chaetomorpha antennina, (Borey.) Kuetz. \\
\hline 7 & Chaetomorpha linum (0. F.Muller) Kuetz. \\
\hline 8 & Cladophora fascicularis, (Merteos) Kuetz. \\
\hline 9 & Enteromorpha compressa, (Linn.)Grev. \\
\hline 10 & Enteromorpha intestinalis, Kuetzing \\
\hline 11 & Ulva facsiata, Delila \\
\hline 12 & Ulva lactuca, Linn. \\
\hline 13 & Ulva reticulata, Forsskal \\
\hline \multicolumn{2}{|c|}{ Phaeophyceae } \\
\hline 14 & Dictyota dichotoma, (Huds.) Lamour. \\
\hline 15 & Padina gymnospora, (Kuetz.) Vickers \\
\hline 16 & Padina tetrastromatica, Hauck. \\
\hline 17 & Sargassum duplicatum, J. Agardh. \\
\hline 18 & Sargassum tenerimum, J. Agardh. \\
\hline 19 & Sargassum wightii, Grev. \\
\hline 20 & Stoechospermum marginatum, (C. Agardh.) Kuetz. \\
\hline \multicolumn{2}{|c|}{ Rhodophyceae } \\
\hline 21 & Acanthophora spicifera, (Vahl.) Boergesen \\
\hline 22 & Amphiroa anceps, (Lamk.) Decsne. \\
\hline 23 & Asparagopsis taxifomis, Delila \\
\hline 24 & Centroceros clavulatum, C. Agardh. \\
\hline 25 & Chondrus sp. \\
\hline 26 & Gelidium pusillum, Stackhouse \\
\hline 27 & Gelidiopsis variabilis, (Grev.) Schmitz \\
\hline 28 & Gracilaria corticata, J. Agardh. \\
\hline 29 & Gracilaria foliifera, (Forsskal) Boergesen \\
\hline 30 & Gracilariopsis lemaneiformis, (Borey) Dawson \\
\hline 31 & Grateloupia filicina, J. Agardh. \\
\hline 32 & Grateloupia lithophila, Boergesen \\
\hline 33 & Hypnea musciformis, (Wulf.) Lamour. \\
\hline 34 & Hypnea valentiae, Mont. \\
\hline 35 & Jania rubens, (Linn.) Lamour. \\
\hline 36 & Laurencia paniculata, J. Agardh. \\
\hline 37 & Pterocladia sp. \\
\hline
\end{tabular}

$\left.238.5 \mathrm{~g} / \mathrm{m}^{2}\right)$ and considerable wet biomass of agar yielding Gelidium pusillum, Gracilaria corticata ( $100 \mathrm{~g} / \mathrm{m}^{2}$ each) as well as $150 \mathrm{~g} / \mathrm{m}^{2}$ of Sargassum wightii in December 1999 (mean wet biomass $299 \mathrm{~g} / \mathrm{m}^{2}$ ). However, during 1999 the number of species 
that could be collected reduced to only 12 although a rarely occurring alginic acid yielding brown seaweed Stoechospermum marginatum was encountered during December (Table 1).

\section{Manassery}

Manassery coast is protected with seawall made of granite boulders and this substratum harboured very few seaweed species. The year 1998 registered a mean harvestable biomass of $62.5 \mathrm{~g} / \mathrm{m}^{2}$ belonging to 4 species and in 1999 these four species of seaweeds registered mean biomass of $50.5 \mathrm{~g} / \mathrm{m}^{2}$ (Table 1). Economically important resources were carrageenan yielding red weeds such as Grateloupia filicina $\left(9.25 \mathrm{~g} / \mathrm{m}^{2}\right.$ in 1998 and $15 \mathrm{~g} /$ $\mathrm{m}^{2}$ in 1999) and Grateloupia lithophila $\left(16 \mathrm{~g} / \mathrm{m}^{2}\right.$ in 1998 and 5 $\mathrm{g} / \mathrm{m}^{2}$ in 1999). Other resources were Chaetomorpha antennina (30.25 g/m $/ \mathrm{m}^{2}$ in 1998 and $26.75 \mathrm{~g} / \mathrm{m}^{2}$ in 1999) and Centroceros clavulatum $\left(6.5 \mathrm{~g} / \mathrm{m}^{2}\right.$ in 1998 and $3.75 \mathrm{~g} / \mathrm{m}^{2}$ in 1999).

\section{Chettikulam}

Chettikulam coast is armoured with many patches of laterite rock formations which serve as ideal substratum for seaweeds and green mussels. During 1998 the mean seaweed biomass that could be harvested was $150 \mathrm{~g} / \mathrm{m}^{2}$ constituted by 12 species and only $141 \mathrm{~g} / \mathrm{m}^{2}$ during 1999 comprising 11 species. Dominant vegetation here was Gracilaria corticata $\left(50 \mathrm{~g} / \mathrm{m}^{2}\right)$ ranging from $25-80 \mathrm{~g} / \mathrm{m}^{2}$ during 1998 and $35 \mathrm{~g} / \mathrm{m}^{2}$ during 1999 showing maximum during December 1998. The subdominant species were green seaweeds Chaetomorpha antennina $\left(22.5 \mathrm{~g} / \mathrm{m}^{2}\right)$ and U/va $\left(14.25 \mathrm{~g} / \mathrm{m}^{2}\right.$ of U/va lactuca and $11.75 \mathrm{~g} / \mathrm{m}^{2}$ of U/va fasciata). No Sargassum sp were encountered during our study period. However, $35 \mathrm{~g} / \mathrm{m}^{2}$ density of Grateloupia lithophila during June 1998, $15 \mathrm{~g} / \mathrm{m}^{2}$ of Hypnea valentiae during September 1998 and $23 \mathrm{~g} / \mathrm{m}^{2}$ of Gelidium pusillum during December 1998 were obtained from this coast. During the year 1999, in addition to Grateloupia lithophila, G. filicina was also encountered (Table 1).

\section{Thikkodi}

Thikkodi coast also has very good laterite rocky substratum to support dense vegetation of seaweeds, estimated with an mean annual wet biomass of $133 \mathrm{~g} / \mathrm{m}^{2}$ during 1998 constituted by 19 species and a mean biomass of $161 \mathrm{~g} / \mathrm{m}^{2}$ during 1999 with 23 species. Rarely occurring red seaweed, Pterocladia sp. $\left(8 \mathrm{~g} / \mathrm{m}^{2}\right)$ during December 1998 and during September 1999 $\left(20 \mathrm{~g} / \mathrm{m}^{2}\right)$, Chondrussp. $\left(20 \mathrm{~g} / \mathrm{m}^{2}\right)$ during December 1999 and brown seaweed Stoechospermum marginatum $\left(18 \mathrm{~g} / \mathrm{m}^{2}\right.$ during December 1998, $35 \mathrm{~g} / \mathrm{m}^{2}$ during June 1999 and $18 \mathrm{~g} / \mathrm{m}^{2}$ during December 1999) were observed from Thikkodi coast. Maximum in the annual biomass of individual species was registered by Gracilaria corticata $\left(41.25 \mathrm{~g} / \mathrm{m}^{2}\right.$ during 1998) and by Sargassum wightii ( $25 \mathrm{~g} / \mathrm{m}^{2}$ during 1999; Table 1).

\section{Dharmadom}

Dharmadom station is in the vicinity of Dharmadom estuary.
Here the seaweed species diversity was not so rich as that of Thikkodi and the annual mean harvestable biomass of seaweeds ranged from $108 \mathrm{~g} / \mathrm{m}^{2}$ during 1999 comprising 13 species to 145 $\mathrm{g} / \mathrm{m}^{2}$ during 1998 formed of only nine species. The dominant species occurring throughout the study period was Gracilaria corticata $\left(51 \mathrm{~g} / \mathrm{m}^{2}\right.$ during 1998 and $47.5 \mathrm{~g} / \mathrm{m}^{2}$ during 1999). The subdominant species was Chaetomorpha antennina. Green seaweed Bryopsis plumosa was recorded during September 1998 as well as during December1999. Considerable quantity of carrageenan yielding red seaweeds Grateloupia filicina and G. lithophila were observed during December 1998 and Hypnea valentiae $\left(35 \mathrm{~g} / \mathrm{m}^{2}\right)$ during December 1999 (Table 1).

\section{Kannur}

Kannur station is characterized by the Mopla Bay housing the Kannur Fisheries Harbour inside and the rocky beach on the northern side. Long thalloid form of red seaweed, Gracilariopsis lemaneiformis was available in the Bay area during March and December of both the years. The annual mean harvestable biomass of seaweeds during 1998 was $129 \mathrm{~g} / \mathrm{m}^{2}$ constituted by 6 species including $38.75 \mathrm{~g} / \mathrm{m}^{2}$ of Gracilariopsis lemaneiformis and $42.5 \mathrm{~g} / \mathrm{m}^{2}$ of Gracilaria corticata ( Table 1). Similarly the annual mean harvestable biomass of seaweeds during 1999 was $125 \mathrm{~g} / \mathrm{m}^{2}$ comprising 9 species dominated by $38.75 \mathrm{~g} / \mathrm{m}^{2}$ of Gracilariopsis lemaneiformis $\left(120 \mathrm{~g} / \mathrm{m}^{2}\right.$ during December) and $32.5 \mathrm{~g} / \mathrm{m}^{2}$ of Gracilaria corticata. Among the carrageenophytes, Grateloupia lithophila was observed during December 1998 (20 $\mathrm{g} / \mathrm{m}^{2}$ ) while, Hypnea valentiae was recorded during December 1999.

\section{Bekal}

Bekal station is situated close to the Bekal Fish Landing Centre and the Bekal Fort surrounded by rock formations which showed mean biomass of $97 \mathrm{~g} / \mathrm{m}^{2}$ during 1998 constituted by 11 species of seaweeds and $114 \mathrm{~g} / \mathrm{m}^{2}$ during 1999 comprising 14 species. While the dominant species during 1998 was Chaetomorpha antennina $\left(24.5 \mathrm{~g} / \mathrm{m}^{2}\right)$, during 1999 it was Gracilaria corticata $\left(28.75 \mathrm{~g} / \mathrm{m}^{2}\right)$. Coralline red algal species Amphiroa anceps was recorded during September 1998 and Jania rubens during December 1999. Carrageenophytes of Bekal during 1998 were represented by four species such as Acanthophora spicifera (June and December), Grateloupia lithophila (December), Hypnea musciformis (except during September) and Hypnea valentiae during September. Similarly carrageenan yielding seaweeds during 1999 were Hypnea musciformis, Acanthophora spicifera during September - December and Grateloupia filicina as well as Hypnea valentiae during December only (Table 1).

\section{Distribution of seaweed resources along the Kerala coast}

From the nine selected stations along the Kerala coast (Fig. 1), a total of 37 species of seaweeds could be collected during 
M. S. Baby Ushakiran et al.

Table 3. Annual mean of water quality parameters of seaweed beds of Kerala coast during 1998 and 1999

\begin{tabular}{|c|c|c|c|c|c|c|}
\hline Stations & Temperature $\left({ }^{\circ} \mathrm{C}\right)$ & $\mathrm{pH}$ & Salinity (ppt) & $\mathrm{DO}(\mathrm{ml} / \mathrm{l})$ & $\mathrm{PO}_{4} \quad(\mu \mathrm{g}$ at/l) & $\mathrm{NO}_{3}(\mu \mathrm{g} \mathrm{at} / \mathrm{l})$ \\
\hline Mullur & $28.84 \pm 1.96$ & $7.57 \pm 0.40$ & $29.95 \pm 2.50$ & $3.69 \pm 0.31$ & $1.33 \pm 0.58$ & $1.57 \pm 0.95$ \\
\hline Dhalavapuram & $29.84 \pm 0.87$ & $6.95 \pm 0.41$ & $21.09 \pm 3.39$ & $3.51 \pm 0.32$ & $1.457 \pm 0.66$ & $2.79 \pm 1.54$ \\
\hline Thirumallavaram & $27.01 \pm 2.09$ & $7.98 \pm 0.07$ & $29.86 \pm 1.95$ & $3.88 \pm 0.36$ & $1.45 \pm 0.37$ & $0.44 \pm 0.19$ \\
\hline Manassery & $28.85 \pm 1.11$ & $7.65 \pm 0.69$ & $29.53 \pm 3.68$ & $3.68 \pm 0.45$ & $0.72 \pm 0.42$ & $0.67 \pm 0.36$ \\
\hline Chettikulam & $29.81 \pm 1.47$ & $7.97 \pm 0.71$ & $33.15 \pm 1.10$ & $4.05 \pm 0.65$ & $1.24 \pm 0.66$ & $1.32 \pm 1.05$ \\
\hline Thikkodi & $30.39 \pm 1.79$ & $8.08 \pm 1.03$ & $30.4 \pm 1.06$ & $4.03 \pm 0.21$ & $1.0 \pm 0.25$ & $1.3 \pm 0.55$ \\
\hline Dharmadom & $27.65 \pm 1.87$ & $7.96 \pm 0.14$ & $30.04 \pm 5.28$ & $4.08 \pm 0.19$ & $0.58 \pm 0.6$ & $2.38 \pm 1.89$ \\
\hline Kannur & $28.56 \pm 1.76$ & $7.89 \pm 0.21$ & $29.81 \pm 1.74$ & $3.98 \pm 0.30$ & $0.353 \pm 0.23$ & $2.0 \pm 0.93$ \\
\hline Bekal & $29.2 \pm 0.78$ & $7.9 \pm 0.32$ & $30.1 \pm 2.38$ & $3.93 \pm 0.68$ & $0.18 \pm 0.3$ & $0.71 \pm 0.37$ \\
\hline
\end{tabular}

1998 and 1999 and they were enlisted in Table 2. Out of the 37 species 13 were grouped under Class Chlorophyceae, 7 under Phaeophyceae (brown seaweeds) and 17 under Rhodophyceae (red seaweeds). Agar yielding seaweeds or the agarophytes that can be harvested for extraction of agar were represented by seven species and the major resources were Gracilaria corticata, G. foliifera, Gelidiopsis variabilis and Gelidium pusillum during 1998 and 1999 besides the species of Pterocladia during 1999. Alginophytes were represented by Sargassum wightii, S. duplicatum, S. tenerimum, Stoechospermum marginatum,
Dictyota dichotoma and Padina spp. The carrageenan yielding red seaweeds were more in number (nine species) belonging to seven Genera. Out of them, Hypnea musciformis, H. valentiae, Grateloupia filicina, Grateloupia lithophila and a new resource Gracilariopsis lemaneiformis from Dhalavapuram and Kannur stations were available in appreciable quantities (Table 1).

\section{Hydrography of seaweed beds of Kerala coast}

The quarterly observation on the seawater quality parameters such as seawater surface temperature (SST), pH, dissolved

Table 4. Pearson Correlation of six hydrographic variables of nine stations

\begin{tabular}{|c|c|c|c|c|c|c|c|c|}
\hline & & Temp. & $\mathrm{pH}$ & Salinity & DO & $\mathrm{PO}_{4}$ & $\mathrm{NO}_{3}$ & Seaweed biomass \\
\hline \multirow[t]{3}{*}{ Temp } & $\begin{array}{l}\text { Pearson } \\
\text { Correlation }\end{array}$ & 1 & 0.160 & $0.249^{*}$ & 0.214 & -0.204 & 0.019 & -0.059 \\
\hline & Sig. (2-tailed) & & 0.181 & 0.035 & 0.071 & 0.086 & 0.871 & 0.625 \\
\hline & $\mathrm{N}$ & 72 & 72 & 72 & 72 & 72 & 72 & 72 \\
\hline \multirow[t]{3}{*}{$\mathrm{pH}$} & $\begin{array}{l}\text { Pearson } \\
\text { Correlation }\end{array}$ & 0.160 & 1 & $0.819^{\star \star}$ & $0.422^{* \star}$ & $-0.360^{\star \star}$ & $-0.395^{\star *}$ & -0.059 \\
\hline & Sig. (2-tailed) & 0.181 & & 0.000 & 0.000 & 0.002 & 0.001 & 0.625 \\
\hline & $\mathrm{N}$ & 72 & 72 & 72 & 72 & 72 & 72 & 72 \\
\hline \multirow[t]{3}{*}{ Salinity } & $\begin{array}{l}\text { Pearson } \\
\text { Correlation }\end{array}$ & $0.249^{\star}$ & $0.819^{\star *}$ & 1 & 0.432 & $-0.244^{*}$ & $-0.586^{\star *}$ & 0.012 \\
\hline & Sig. (2-tailed) & 0.035 & 0.000 & & 0.000 & 0.039 & 0.000 & 0.919 \\
\hline & $\mathrm{N}$ & 72 & 72 & 72 & 72 & 72 & 72 & 72 \\
\hline \multicolumn{9}{|l|}{ DO } \\
\hline & $\begin{array}{l}\text { Pearson } \\
\text { Correlation }\end{array}$ & 0.214 & $0.422^{\star \star}$ & $0.432^{\star \star}$ & 1 & $-0.260^{*}$ & -0.106 & -0.006 \\
\hline & Sig. (2-tailed) & 0.071 & 0.000 & 0.000 & & 0.027 & 0.375 & 0.961 \\
\hline & $\mathrm{N}$ & 72 & 72 & 72 & 72 & 72 & 72 & 72 \\
\hline \multirow[t]{3}{*}{$\mathrm{PO}_{4}$} & $\begin{array}{l}\text { Pearson } \\
\text { Correlation }\end{array}$ & -0.204 & $-0.360^{\star \star}$ & -0.244 & -0.260 & 1 & 0.071 & $0.422^{\star \star}$ \\
\hline & Sig. (2-tailed) & 0.086 & 0.002 & 0.039 & 0.027 & & 0.553 & 0.000 \\
\hline & $\mathrm{N}$ & 72 & 72 & 72 & 72 & 72 & 72 & 72 \\
\hline \multirow[t]{3}{*}{$\mathrm{NO}_{3}$} & $\begin{array}{l}\text { Pearson } \\
\text { Correlation }\end{array}$ & 0.019 & $-0.395^{\star \star}$ & $-0.586^{\star *}$ & -0.106 & 0.071 & 1 & -0.049 \\
\hline & Sig. (2-tailed) & 0.871 & 0.001 & 0.000 & 0.375 & 0.553 & & 0.683 \\
\hline & $\mathrm{N}$ & 72 & 72 & 72 & 72 & 72 & 72 & 72 \\
\hline \multirow[t]{3}{*}{$\begin{array}{l}\text { Sea weed } \\
\text { biomass }\end{array}$} & $\begin{array}{l}\text { Pearson } \\
\text { Correlation }\end{array}$ & -0.059 & -0.059 & 0.012 & -0.006 & $0.422^{\star \star}$ & -0.049 & 1 \\
\hline & Sig. (2-tailed) & 0.625 & 0.625 & 0.919 & 0.961 & 0.000 & 0.683 & \\
\hline & $\mathrm{N}$ & 72 & 72 & 72 & 72 & 72 & 72 & 72 \\
\hline
\end{tabular}


oxygen, dissolved phosphates and nitrates determined for a period of two years from nine seaweed growing areas along the Kerala coast are presented as annual mean in Table 3. Annual mean of SST registered maximum of $30.39^{\circ} \mathrm{C}$ in Thikkodi $\left(32.9^{\circ} \mathrm{C}\right.$ during March 1999 to $27.9^{\circ} \mathrm{C}$ during September 1998) and minimum of $27.01^{\circ} \mathrm{C}$ at Thirumallavaram with a range of $29.2^{\circ} \mathrm{C}$ during March 1999 to $24.2^{\circ} \mathrm{C}$ during June 1998 . Similarly $\mathrm{pH}$ also registered maximum of 8.08 in Thikkodi and a minimum of 6.95 in Dhalawapuram. Dhalawapuram, being the estuarine station registered highest annual mean values of dissolved nitrate and phosphate levels. The northern stations of Kerala coast recorded gradual reduction in phosphate levels (Table 3).

When the hydrographic data from the seaweed growing sites was statistically analysed, very high significant positive correlation could be observed between salinity and pH. Though not high, there was significant positive correlation between $\mathrm{pH}$ and dissolved oxygen as well as salinity and dissolved oxygen $(p<0.01)$. There was also significant negative correlation (Table 4) between $\mathrm{pH}$ and $\mathrm{PO}_{4}, \mathrm{pH}$ and $\mathrm{NO}_{3}$ and Salinity and $\mathrm{NO}_{3}(\mathrm{p}<0.01)$, Salinity and $\mathrm{PO}_{4}, \mathrm{O}_{2}$ and $\mathrm{PO}_{4}(\mathrm{p}<0.05)$.

\section{Discussion}

Water quality plays an important role in the occurrence and distribution of seaweeds. Seawater quality parameters such as sea surface temperature (SST), pH, dissolved oxygen, dissolved phosphates and nitrates were determined quarterly for a period of two years from nine seaweed growing areas along the Kerala coast. The mean values of SST showed a minimum at Thirumallvaram and the maximum at Thikkodi. Higher mean value of SST at Thikkodi than in other locations might be due to the depth and rocky nature of coast. Since Dhalavapuram is a brackish water station, the mean values of $\mathrm{pH}$ and salinity recorded were minimum and matched with the higher $\mathrm{PO}_{4}$ and $\mathrm{NO}_{3}$ levels received from the upstream areas.

The southwest monsoon plays a major role in deciding the hydrographic parameters of Arabian Sea in general and the sea adjoining Kerala coast extending to the Laccadive Sea in particular. Highest temperatures were observed in the Laccadive Sea before and after the south west monsoon period, whereas during the monsoon period the SST was low (Sewel, 1929). Observations of SST near Calicut by Chidambaram (1950), George (1953), Sheshappa and Jayaraman (1956) and Kasturirangan (1957) indicated that after an annual maximum of SST in April/May of about $30^{\circ} \mathrm{C}$, there is a reduction in June although in some years the monthly average temperature began to decrease by May itself. In the present investigation also similar pattern was exhibited along the Kerala coast. Maximum SST was observed in April (Table 3) as understood by Sankaranarayanan and Qasim (1969) and Pillai (1991).

The salinity of seawater showed a decline during the southwest monsoon period as reported that the variation in the sea water salinity during monsoon in the intertidal region is mainly brought about by rainfall and river runoff (Pillai, 1991). The dissolved oxygen levels observed were normal and remained well aerated. However, in the off sea near the continental shelf the presence of low oxygen concentrations between Kasaragod and Quilon during the south west monsoon period was reported by Pillai (1993). Upwelling is a process normally associated with the south west monsoon which brings in nutrient rich subsurface waters to the sea surface. Besides upwelling, nutrient enrichment in coastal waters does occur through river runoff and land runoff during the monsoon period (Atkins, 1923) which is significant in the enrichment of seawater near the river mouths. In the present study most of the stations registered higher nutrient $\mathrm{NO}_{3}$ and $\mathrm{PO}_{4}$ ) status during the south west monsoon period (June-September) which is well supported by the findings of earlier studies (George, 1953; Seshappa and Jayaraman, 1956; Jayaraman and Seshappa, 1957; Sankaranarayanan and Qasim, 1969). This monsoon induced hike in dissolved $\mathrm{PO}_{4}$ and $\mathrm{NO}_{3}$ supports the blooming of phytoplankton along the west coast (Balachandran et al., 1997) is applicable in the present study also that postmonsoon period of both 1998 and 1999 registered considerable increase in the harvestable biomass of seaweeds.

From the nine selected Stations along the Kerala coast, a total of 37 species of seaweeds could be collected. Although Balakrishnan Nair et al. (1982) claimed to have recorded 44 species of marine algae from southern Kerala coast including the Ashtamudi Lake systems, two were identified as seagrasses (marine angiosperms). Chennubhotla et al (1988) observed 34 species of marine algae from entire Kerala coast during the seaweed assessment survey they conducted. He and his team later added one more species of red seaweed Porphyra kanyakumariensis from Kerala coast (Chennubhotla et al., 1990) which was not encountered during the present study. Later Kaliaperumal and Chennubhotla (1997) described only 35 species belonging to 28 genera and 18 families after conducting seaweed resource assessment survey along the Kerala coast from 15 localities.

Recently Nettar and Panikkar (2009) described two new species from the Family Ralfsiaceae, Hapalospongidion thirumullavaramensis and Pseudolithoderma thangasseriensis, collected from the Quilon coast of Kerala. The taxonomy of four species of Feldmannia collected from different parts of Kerala such as F. collumellaris, F. irregularis and two new species: F. sahnienii and $F$. renienii was also reported by Nettar and Panikkar (2009a). Nettar and Panikkar (2009b) reported five species of Hincksia collected from different parts of Kerala and these include, $H$. clavata (Krishnamurthy and Baluswami) Silva, H. rallsiae (Vickers) Silva, H. sandriana (Zanardini) Silva, H. mitchelliae (Harvey) Silva and H. turbinariae (Jaasund) Silva. Among these, $H$. rallsiae is a new report to the Indian marine 
flora. Nettar (2009) described with illustrations the occurrence of Hecatonema: H. sargassicola Boergesen and $H$. terminale (Kuetzing) Kylin, collected from Kerala and Tamil Nadu.

Agar yielding seaweeds or the agarophytes that can be harvested for extraction of agar from Kerala coast were represented by seven species and the major resources were Gracilaria corticata, G. foliifera, Gelidiopsis variabilis and Gelidium pusillum during 1998 and 1999 besides the species of Pterocladia during 1999. Alginophytes were represented by Sargassum wightii, S. duplicatum, S. tenerimum, Stoechospermum marginatum, Dictyota dichotomaand Padinaspp. The carrageenan yielding red seaweeds were Hypnea musciformis, $H$. valentiaeand a new resource Gracilariopsis lemaneiformisfrom Dhalavapuram and Kannur stations.

The nine sampling locations were compared using ANOVA followed by SNK test for testing their significant difference in the harvestable biomass production of two species of seaweeds, Chaetomorpha antennina and Gracilaria corticata which occurred in all the locations and almost throughout the study period. This analysis revealed that the harvestable biomass of Chaetomorpha antennina was significantly different $(p<0.01)$ between different sampling locations which can be grouped into two homogenous groups. In the first grouping, among the eight marine locations, Dharmadam stations was significantly different from all other locations with regard to occurrence of Chaetomorpha antennina, whereas in the second grouping Thirumallavaram, Mullur andThikkodi were significantly different from rest of the study locations.

In the case of Gracilaria corticata ANOVA results have shown that all locations are homogenous with respect to biomass availability. Multiple regression analysis carried out to examine predictability of harvestable seaweed biomass with the help of water quality variables such as SST, salinity, DO and dissolved nutrient levels yielded low but significant $R^{2}(0.198, p<0.05)$ and the regression coefficient was significant only for phosphate which is corroborated by observations made by Chennubhotla et al. (1990). It could be inferred that a synergistic effect of all these parameters existing in a water body can be held responsible for seasonal and spatial variation in the seaweed biomass production along the Kerala coast.

Seaweed resource assessment carried out from Mullur to Bekal along the Kerala coast indicated rich quantity $(70-75 \%$ ) of non commercially important species such as Chaetomorpha antennina, Ulva reticulata, Ulva fasciata, Ulva lactuca, Caulerpa peltata, C. racemosa, Bryopsis plumosa, Enteromorpha compressa and Chaetomorpha linum. Similar estimates made from five States including Lakshadweep islands (Umamaheswara Rao, 2011) unraveled that the resources available for agar, algin and carrageenan production are about $9 \%$ of the total seaweed resources of our country and the remaining $91 \%$ are either unutilized or underutilized. However, these underutilized seaweed resources can be utilized for the production of nutraceuticals, manure and cattle feed.

\section{References}

APHA. 1998. Standard Methods for the Examination of water and wastewater. American Public Health Association. 19th edition, Washington. pp 1132.

Atkins, W.R.G. 1923. Phosphate content of freshand salt waters in its relationship to algal plankton. J.Mar. Biol. Ass. U.K., 13: 119-150.

Baby Ushakiran, M. S., M. V. Merlee Treesa and P. Kaladharan. 2014. A review on resources, cultivation and utilisation of marine macroalgae in India. Seaweed Res. Utiln., 36 (1 \& 2): 114-125

Balachandran, V. K., C. P. Gopinathan, V. K. PIllai, A. Nandakumar and K. K. Valsala. 1997. Chlorophyll profile of the euphotic zone in the Lakshadweep Sea during the southwest monsoon season. Indain J. Fish., 41(1): 29 - 43.

Balakrishnan Nair, N., V. Sobha and M. Arunachalam. 1982. Algae from southern Kerala coast. Indian J. Mar. Sci., 11: 266-269.

Balakrishnan Nair, N., V. Sobha, R. Chandran, M. Rathiammal, P. I. Miranda, S. Maya and H. Suryanarayanan. 1986. Algal resources of Kerala coast II. An up-to-date list of Indian marine algae. Aqua. Biol., 6:25-52.

Balakrishnan Nair, N., V. Sobha, R. Chandran, P. A. Paul, P. I. Miranda and H. Suryanarayanan. 1986 a. Nature and distribution of the littoral algae and seagrasses of the southeast coast of India. Proc. Indian Nat. Sci. Acad., B 52: 733-744.

Balakrishnan Nair, N., V. Sobha, R. Chandran, M. Rathiammal, P. I. Miranda, S. Maya and H. Suryanarayanan. 1990. Algal resources of Kerala coast IX. Occurrence and relative abundance of Chlorophyceae along southeast coast of India. Seaweed Res. Utiln., 12 (1\&2): 125-135.

Balakrishnan Nair, N., V. Sobha, R. Chandran, M. Rathiammal, S. Maya and H. Suryanarayanan. 1993. Algal resources of Kerala coast. VIII. Occurrence and relative abundance of Rhodophyta. Seaweed Res. Utiln., 16 (1\&2): 183-197.

Chennubhotla, V. S. K. 1996. Seaweeds and their importance. CMFRI Bull. Artificial reefs and Seafarming technologies, 48: 108-109.

Chennubhotla, V. S. K., B. S. Ramachandrudu, P. Kaladharan and S. K. Dharmaraja. 1988. Seaweed resources of Kerala Coast. Bulletin of the Department of Aquatic Biology and Fisheries, 7: 69-74.

Chennubhotla, V. S. K., Mathew Susan and Imelda Joseph. 1990. A note on the occurrence of Porphyra kanyakumarjensis (Bangiales: Rhodophyta) along the Kerala coast. Seaweed Res. Utiln., 13 (1):1-4.

Chidambaram, K. 1950. Studies on the length frequency of the oilsardine, Sardinella longiseps, Cuv. \& Val. and on certain factors influencing on the Calicut coast of Madras Presidency. Proc. Indian Acad. Sci., 31 B (5): 252-286.

Devaraj, M. V. K. Pillai, K. K. Appukuttan, C. Suseelan, V. S. R. Murty, P. Kaladharan, G. S. Rao, N. G. K. Pillai, N. N. Pillai, K. Balan, V. Chandrika, K. C. George and K. S. Sobhana. 1999. Packages of Practices for Sustainable; Ecofriendly Mariculture (Land-based Saline Aquaculture and Seafarming). In: Aquaculture and the Environment. Mohan Joseph, M, (Ed.) Asian Fisheries Society, Mangalore, p 33-70.

George, P. C. 1953. The marine plankton of the coastal waters off Calicut with observation on the hydrobiological conditions. J. Zool. Soc. India, 5: 76- 107.

Jayaraman, R. and G. Seshappa. 1957. Phosphorous cycle in the sea with particular reference to tropical inshore waters. Proc. Indian Acad. Sci., 46: 11-125.

Kaladharan, P. 2005. Gracilariopsis lemaneiformis (Bory) Dawson - a red alga reported from certain backwaters of Kerala. J. Bom. Nat. Hist. Soc., 102 (3): 378-379.

Kaliaperumal, N. 1993. Seaweed culture. In: Handbook on Aquafarming-Seaweed, Seaurchin and Seacucumber, MPEDA, Cochin. p 1-22.

Kaliaperumal, N. and V. S. K. Chennubhotla. 1997. Seaweed distribution and resources in Kerala coast. Seaweed Research and Utilisation, 19 (1\&2): 29-32.

Kasturirangan, L. R. 1957. A study of the seasonal changes in the dissolved oxygen of the surface waters of the sea on the Malabar Coast. Indian J. Fish., 4 (1): 134149.

Morris, E. P. and J. P. Riley. 1963. The determination of nitrate in seawater. Anal. Chim. Acta., 29: 272- 279.

Murphy, J. and J. P. Riley. 1962. A modified single solution method for the determination of phosphate in natural waters. Anal. Chim. Acta., 27: 31-36.

Nettar, S. P. 2009. Phaeophyceae of South India-V. Hecatonema Sauvageau (Chordariales, Phaeophyceae). Seaweed Research and Utilisation, 31 (1\&2): 25-28.

Nettar, S. P. and M. V. N. Panikkar. 2009. Two new brown algal species from the Family Ralfsiaceae (Ectocarpales, Phaeophyceae) from Kerala, India. Seaweed Research and Utilisation, 31 (1\&2): 7-10. 
Nettar, S. P. and M. V. N. Panikkar. 2009a. Species of Feldmannia Hamel (Ectocarpales, Phaeophyceae) from Kerala, India. Seaweed Research and Utilisation, 31 (1\&2): 11-16.

Nettar, S. P. and M. V. N. Panikkar. 2009b. Species diversity of Hincksia Gray (Ectocarpales, Phaeophyceae) from the Kerala coast of India. Seaweed Research and Utilisation, 31 (1\&2): 17- 32.

Oza, R.M. and S. H. Zaidi. 2001. A Revised Checklist of Indian Marine Algae. Central Salt and Marine Chemicals Research Institute, Bhavnagar, Gujarat. 296 pp.

Parsons, T. R., M. Yoshiaki and L. Carol. 1984. A Manual of Chemical and Biological Methods for Seawater Analysis. 101-104 pp.

Pillai, V. N. 1991. Salinity and thermal characteristics of the coastal waters off South West Coast of India and their relation to major pelagic fisheries of the region. J. Mar. Biol. Assn. India, 33(1\&2): 115-133.

Pillai, V. N. 1993. Variations in dissolved oxygen content of coastal waters along south west coast of India in space and time. Indian J. Mar. Sci., 22: 279- 282.
Sankaranarayanan, V. N. and S. Z. Qasim. 1969. The influence of some hydrographical features on the fisheries of the Cochin area. Bull. Nat. Inst. Sci. India, 38: 846853.

Seshappa, G. and R. Jayaraman. 1956. Observations on the composition of the bottom mud in relation to the phosphate cycle in the inshore waters of the Malabar Coast. Proc. Indian Acad. Sci., 43 B: 288 - 301.

Sewel, R. B. S. 1929. Geographic and oceanographic research in Indian waters. Mem. Asia. Soc. Bengal, 9(5): 207- 356.

Umamaheswara Rao, M. 1969. Seasonal variations in growth, alginic acid and mannitol contents of Sargassum wightii and Turbinaria conoides from the Gulf of Mannar, India.In: Proc. Intl. Seaweed Symp., 6: 579-584.

Umamaheswara Rao, M. 1987. Key for identification of economically important seaweeds. Bull. Cent. Mar. Fish. Res. Inst., No 41: 19-25.

Umamaheswara Rao, M. 2011. Diversity and commercial feasibility of marine macroalgae of India. Seaweed Res.Utiln, 33 (1\&2):1-13. 